\title{
Utilizing Remote Sensing and GIS to Detect Prairie Dog Colonies
}

\author{
Timothy J. Assal ${ }^{1}$ and Jeffrey A. Lockwood ${ }^{2}$ \\ Authors are ${ }^{1}$ Instructor, Department of Social and Behavioral Sciences, Front Range Community College, Fort Collins, CO \\ 80526; and ${ }^{2}$ Professor, Department of Renewable Resources, University of Wyoming, Laramie, WY 82071.
}

\begin{abstract}
The locations of black-tailed prairie dog (Cynomys ludovicianus [Ord]) colonies on a 550- $\mathrm{km}^{2}$ study site in northeastern Wyoming, United States, were estimated using 3 remote sensing methods: raw satellite imagery (Landsat 7 ETM+), enhanced satellite imagery (integration of imagery with thematic layers via a Geographic Information System), and aerial reconnaissance (observations taken from a small plane). A supervised classification of the raw satellite imagery yielded an overall accuracy of $64.4 \%$, relative to ground-truthed locations of prairie dog colonies. The enhanced satellite imagery, resulting from a filtering of the data based on an index derived from the sum of weighted ecological factors associated with prairie dog colonies (slopes, land cover, soil, and "greenness" via the Normalized Difference Vegetation Index) yielded an overall accuracy of $69.2 \%$. The aerial reconnaissance method provided $65.1 \%$ accuracy. The highest rate of false positives resulted from the aerial reconnaissance method $(39.9 \%)$. The highest rate of false negatives resulted from the raw satellite imagery $(60.0 \%)$, a value that was markedly reduced via the enhancement with ecological data from thematic layers $(45.8 \%)$. Given the accuracy, interpretability of results, repeatability, objectivity, cost, and safety, the enhanced satellite imagery method is the recommended approach to large-scale detection of black-tailed prairie dog colonies. If a greater accuracy is required, this method can be employed as a coarse filter to narrow the scale and scope of a more costly and laborious fine-scale analysis effectively.
\end{abstract}

\section{Resumen}

La localización de las colonias de perritos de la pradera de cola negra (Cynomys ludovicianus [Ord]) en un sitio de estudio de $550 \mathrm{~km}^{2}$ en el nordeste de Wyoming se estimaron usando tres métodos de sensores remotos: imágenes de satélite (Landsat 7 ETM+) "puras," imágenes de satélite mejoradas (integración de las imágenes de satélite con capas temáticas vía Sistemas de Información Geográfica) y reconocimiento aéreo (observaciones tomadas de aviones pequeños). La clasificación supervisada de las imágenes de satélite "puras" produjeron una precisión general del $64.4 \%$, en relación con las localizaciones verdaderas de las colonias de los perritos de la pradera verificadas en tierra. Las imágenes de satélite mejoradas, resultantes del filtrado de los datos en base a un índice derivado de la suma de los factores ecológicos ponderados asociados con las colonias de los perritos de la pradera (pendientes, cobertura vegetal, "verdor" derivado a través del Índice de Vegetación de Diferencia Normalizada) produjo una precisión general de $69.2 \%$. La precisión del método de reconocimiento aéreo fue del $65.1 \%$. La mayor tasa de falso-positivos resultó del método de reconocimiento aéreo (39.9\%). La tasa más alta de falso-negativos se obtuvo con los datos de las imágenes de satélite "puras" $(60.0 \%)$, un valor que fue reducido marcadamente al mejorar las imágenes con los datos ecológicos de las capas temáticas $(45.8 \%)$. Dada la precisión, interpretabilidad de los resultados, repetibilidad, objetividad, costo y seguridad, las imágenes de satélite mejoradas es el método recomendado para la detección a gran escala de las colonias de perritos del a pradera de cola negra. Si se requiere una mayor exactitud, este método puede emplear como un filtro grueso para reducir efectivamente la escala y alcance de un análisis a escala fina más costo y laborioso.

Key Words: black-tailed prairie dogs, conservation biology, habitat detection, habitat monitoring, satellite imagery

\section{INTRODUCTION}

Remote sensing has emerged as a viable option to monitor and detect wide-ranging wildlife populations in poorly accessible regions (Wallin et al. 1992; Prasad et al. 1994; Porwal et al. 1996; Verlinden and Masogo 1997)—qualities that define the

Research was funded in part by the Upper Midwest Aerospace Consortium, Wyoming Department of Agriculture, and Wyoming Game and Fish Department. The United States Forest Service also provided logistical support for this project.

At time of research, the senior author was Research Assistant, Dept of Botany, University of Wyoming, Laramie, WY 82071

Correspondence: Timothy J. Assal, Dept of Social and Behavioral Sciences, Front Range Community College, Fort Collins, C0 80526. Email: tim.assal@frontrange.edu

Manuscript received 24 June 2005; manuscript accepted 22 October 2006. ecology of the black-tailed prairie dog. As such, the use of satellite imagery has become an attractive choice as a possible means to detect black-tailed prairie dog colonies over their range. We propose that prairie dog colonies be considered a distinct patch in the grassland matrix, because prairie dogs expose more of the soil surface when the vegetation is clipped, lowering the overall height of the vegetation, as well as the amount of canopy cover on the colony. They also remove all of the vegetation from small areas around burrow entrances through excavation. This behavior, however, has less of an influence on the overall spectral response of a colony. Based on an understanding of the soil and vegetation spectral signatures, we hypothesized that prairie dog colonies could be detected with the use of affordable and readily available satellite imagery, such as that provided by Landsat 7 Enhanced 
Thematic Mapper (ETM+). We further posited that this approach could be more efficient, less costly, and as accurate as aerial reconnaissance.

Past research indicates that black-tailed prairie dog colonies are nonrandomly distributed throughout the species' range, being associated with several key landscape features, such as slopes and soils (Koford 1958; Dalsted et al. 1981; Reading and Matchett 1997). These attributes can be used to help identify areas of potential habitat, as well as rule out areas that cannot support prairie dogs as a means of refining satellite imagery. Past studies have successfully integrated remotely sensed data with a GIS (Jorge and Garcia 1997; McGregor 1998; Wu and Smeins 2000; Latchininsky 2001). We tested 4 hypotheses concerning the spatial ecology of prairie dogs, predicting that their colonies would: 1 ) be preferentially distributed across the landscape of the study area with respect to shallow slopes, 2) have more frequent association with particular habitat types (i.e., mixed-grass prairie), 3) be preferentially distributed across the landscape with respect to deep, well-drained soils, and 4) have a lower Normalized Difference Vegetation Index (NDVI) than adjacent grassland, because of less vegetation and greater amounts of exposed soil on colonies. We compared the accuracy of classifications based on Landsat Enhanced Thematic Mapper data alone and on an integrated model that used ancillary data to augment the imagery. Finally, we compared the results of these 2 satellite imagery techniques (raw and enhanced data) with aerial reconnaissance.

\section{MATERIALS AND METHODS}

\section{Study Area}

The study site was located within Thunder Basin National Grassland (TBNG), between $104.9^{\circ} \mathrm{W}$ and $105.3^{\circ} \mathrm{W}$ longitude and $43.3^{\circ} \mathrm{N}$ and $43.6^{\circ} \mathrm{N}$ latitude (Fig. 1). Annual precipitation in the study area is $300 \mathrm{~mm}$ and the mean annual temperature is $8.1^{\circ} \mathrm{C}$. The vegetation is primarily mixed-grass prairie, interspersed with sagebrush shrublands; sparse woodlands are found on eastward facing escarpments. The nested study area was divided into an outer area $\left(2940 \mathrm{~km}^{2}\right)$ and an inner area $\left(550 \mathrm{~km}^{2}\right)$ for methods development and modeling purposes. The outer area was used to gather statistical information from prairie dog colonies from which procedures/models were developed, and the inner area was used for validation by aerial recognizance. Both areas were chosen based on the existence of diverse landscape features, contiguous public lands, the availability of ground-based survey data on prairie dog colonies, and other logistical considerations.

\section{Acquisition and Correction of Satellite Imagery}

A Landsat 7 Enhanced Thematic Mapper (ETM+) satellite image was acquired from the US Geological Survey. ETM+ provides a spatial resolution of $30 \times 30 \mathrm{~m}$ in bands $1-5$ and 7 , $60 \times 60 \mathrm{~m}$ in band 6 , and $15 \times 15 \mathrm{~m}$ in the panchromatic band. The study area was extracted from ETM+ scene L7103430_03020000719, corresponding to Path 34 and Row 30 . The image was recorded on 19 July 2000, and represented a cloud-free scene. Based on a preliminary investigation, this time of year represented the greatest contrast between prairie dog colonies and surrounding vegetation, because vegetation was at peak biomass and cover.

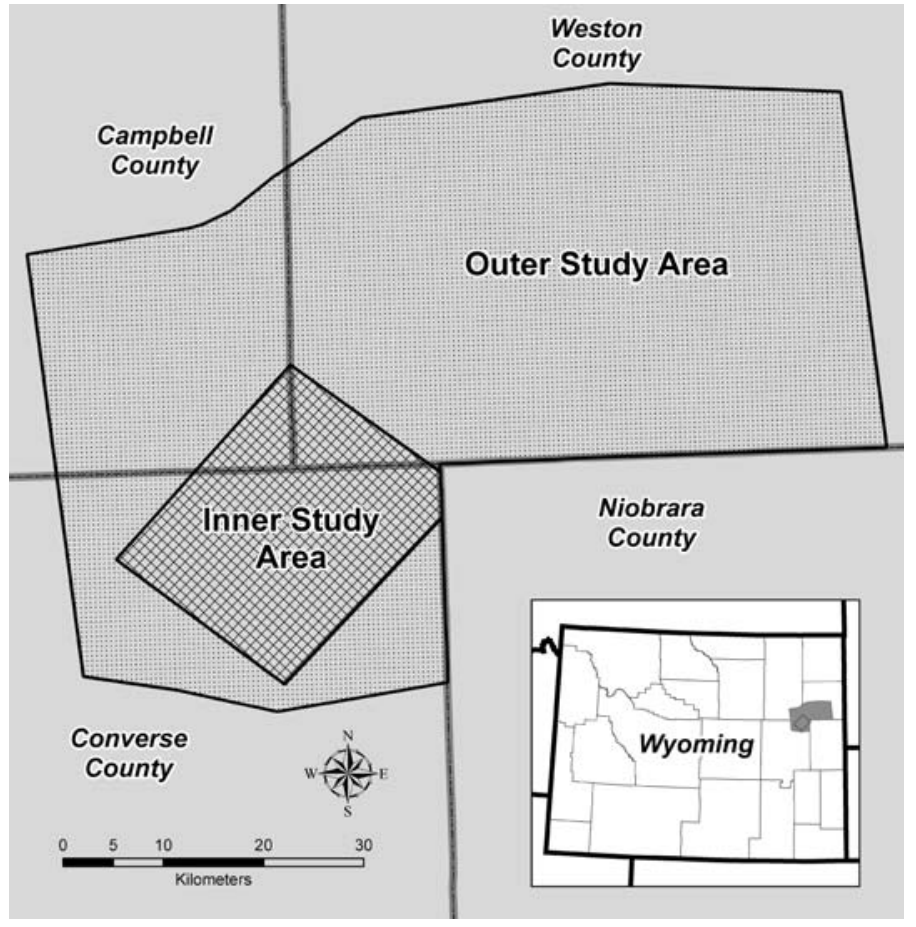

Figure 1. The nested study area located in northeastern Wyoming, United States. Map was created using ArcView GIS 9.1.

The original image was radiometrically and geometrically corrected by the supplier of the data using the nearest neighbor technique. The geometric alignment of the bands was unsatisfactory, so they were geographically referenced again to ensure correct alignment. The 27 ground control points consisted of linear features (e.g., road and pipeline intersections) and natural features (e.g., stream intersections and water boundaries, resulting in a root-mean-square error of 1.17 and 0.84 for the panchromatic and multispectral bands, respectively.

A resolution merge was conducted, with the use of the panchromatic band as the base image, resulting in a spatial resolution of $15 \times 15 \mathrm{~m}$ for the multispectral images. A simple false color composite (bands 4,3 , and 2) was determined to provide the greatest contrast between colonies and adjacent land, by visual comparison with other band combinations.

\section{Acquisition of GIS Data}

The GIS contained information on location of prairie dog colonies, land cover, soil type, slope, and the Normalized Difference Vegetation Index (NDVI = NIR band-red band/ NIR band + red band) for the study area. A U.S. Forest Service crew mapped the extent of prairie dog colonies in the TBNG during the summers of 1996 and 1997 with the use of a Geographic Positioning System (GPS) to record colony location and size. Land cover for the area, at a scale of 1:100 000, was obtained from the Wyoming Geographic Information Science Center (Wyoming Gap Analysis 1996).

Soil data for TBNG were produced by the Natural Resource Conservation Service, obtained from the Soil Survey Geographic (SSURGO) database at a scale of 1:24 000, and represented the finest digital soil data available for this area. The slope data were 


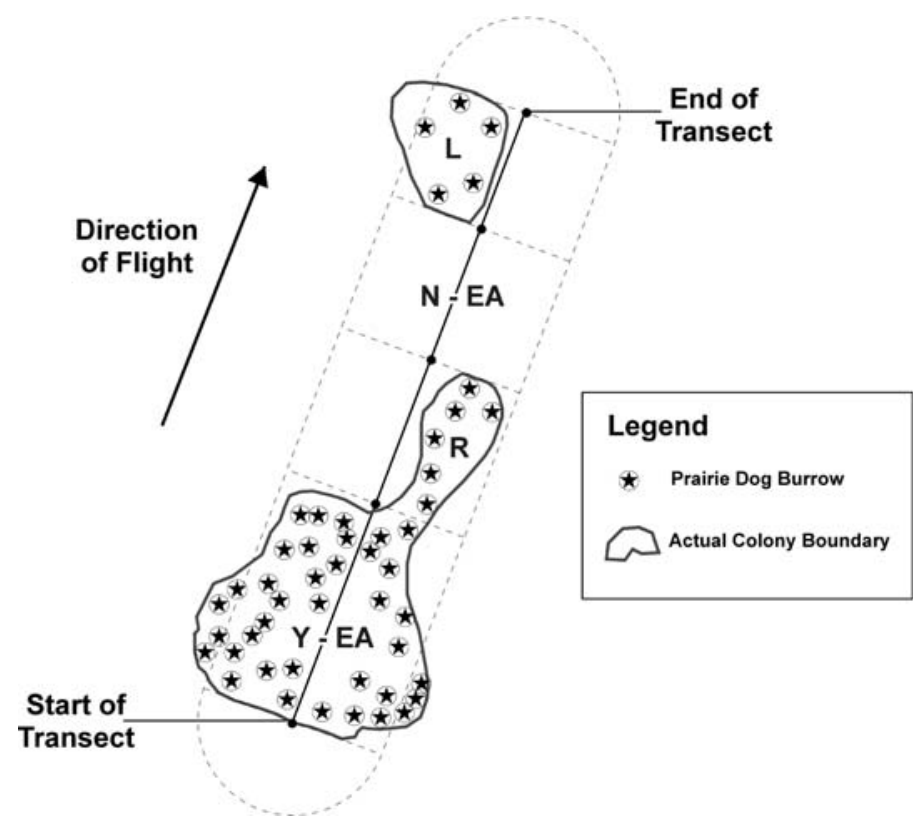

Figure 2. Schematic of a single aerial transect with the $800-\mathrm{m}$ buffer. Each point has attribute data regarding the presence or absence of a prairie dog colony. (Y-EA = colony, either area; $\mathrm{N}-\mathrm{EA}=$ no colony, either area; $R=$ colony on right side only; $L=$ colony on left side only.)

derived from a 30-m digital elevation model, which was produced by the U.S. Geological Survey (1999).

The Normalized Difference Vegetation Index was calculated by the method of Rouse et al. (1974), with Landsat bands 4 and 3 representing the near-infrared and red range of the electromagnetic spectrum, respectively. The data from the image were grouped into 10 classes by multiplying the total histogram value by $10 \%$. Class 10 had values with the highest NDVI, whereas class 1 had the lowest NDVI values.

\section{Acquisition of Aerial Reconnaissance Data}

A Cessna 210 was flown over the study area between 25 June and 28 June 2001 at approximately $152 \mathrm{~m}$ above ground level, at speeds from 145 to $160 \mathrm{~km} / \mathrm{hour}$, by the Wyoming Game and Fish Department. Prairie dog towns were surveyed by methods described by Sidle et al. (2001). Observations of prairie dog colonies were recorded $800 \mathrm{~m}$ ( 0.5 mile) on either side of a transect and a position was recorded by an observer in the plane with a GPS each time the flight path intersected the edge of a visible prairie dog town (burrow mounds). The location of the town was recorded as either right, left, or both (entire area), with regard to the flight path. Another GPS position was marked each time the flight path left the prairie dog town (Fig. 2). The observer was unable to determine if the town was active because prairie dogs were rarely seen due to a recent plague event and some of the usual indicators (e.g., lack of vegetation on burrow mounds) were obscured by drought conditions that had persisted for the previous 3-4 years.

\section{Acquisition of Field Data}

A total of 247 ground sites were visited during the summer of 2001. The sites were randomly stratified based on the existing
GIS colony layer (Stehman and Czaplewski 1998). Of the 247 sites, 120 were located on prairie dog colonies, based on the GIS layer. The remaining 127 sites were located on noncolony areas. Any random point that fell either on private land or $>500 \mathrm{~m}$ from a road was discarded to assure reasonable access to sites. There was no reason to believe that primitive roads in the study area were preferentially distributed with respect to landscape or ecological features. A $100-\mathrm{m}^{2}$ plot was set up around each random point and the class (colony or noncolony) was determined for each area. At each site the location was recorded using a GPS unit (Trimble GeoExplorer 3; 2-5-m accuracy), a color photograph was taken, the approximate slope and aspect were recorded, and notes on the vegetation and amount of exposed soil were made.

\section{Satellite Imagery Analysis}

An unsupervised classification was performed with the use of the iterative self-organizing data analysis technique (ISODATA) on the false color composite (Tou and Gonzalez 1974) to reduce the quantity of data. This procedure resulted in 15 classes, 4 of which were discarded because they did not contain areas of potential habitat for black-tailed prairie dogs. The remaining 11 classes were used to generate a mask file, which was applied to the image. The new image contained spectral information with a more narrow range of values, and approximately $65 \%$ of the image was included by the mask.

A supervised classification was then performed on the masked image using ERDAS IMAGINE ${ }^{\circledR}$ (Leica Geosystems Geospatial Imaging, Norcross, GA). Based on knowledge of the area and fieldwork from the summers of 2000 and 2001, spectral signatures in the outer study area were defined for various landscape features identified. A parallelepiped classifier was selected to compare the spectral signature of each pixel in the inner study area to the training set signatures; then each pixel was assigned to a landscape type based on the closest training set signature (Wilkie and Finn 1996).

\section{GIS Data Analysis}

All GIS data processing was prepared with the use of ArcView ${ }^{\circledR}$ version 3.2, $\operatorname{ArcMap}^{\circledR}$ version 9.1, and $\mathrm{ARC} / \mathrm{INFO}^{\circledR}$ version 7.2 (ESRI; Redlands, CA), using the Universal Transverse Mercator (UTM) Zone 13 North coordinate system. All of the vector GIS coverages were converted to raster format, and resampled to $15 \mathrm{~m}$ to maintain consistency with the image.

All 5 GIS data layers were separated into the inner and outer study areas.

The portions of the outer study area layers were then clipped to fit the colonies located in this area. Thus, the resulting layers contained only pixels representing the slope, land cover, soil type, and NDVI from prairie dog colonies in the outer study area, which would be used to calculate the expected amount of each attribute.

The relationship between the observed and expected amount of an attribute was then analyzed with the use of a chi-square test for each site (Lloyd 1999; Wheater and Cook 2000). The degrees of freedom varied for each test, but the $\alpha$ value was held constant at $P=0.05$. If the null hypothesis was rejected, each attribute's individual contribution to the total $\chi^{2}$ value was analyzed. Each attribute was given a score based on a modified 
logarithm scale (a score of 0 was assigned if the $\chi^{2}$ value was not significant; a score of 1 if the $\chi^{2}$ value was 3.85 to 10 ; a score of 2 if the $\chi^{2}$ value was 11 to 100 ; a score of 3 if the $\chi^{2}$ value was 101 to 1000 ; a score of 4 if the $\chi^{2}$ value was $>1$ 000). The scores were then transferred to the corresponding attributes located in the inner study area for each layer.

The GIS data were then integrated with the satellite imagery to produce the enhanced satellite imagery, divided into potential habitat, and assigned a specific sized filter. The scores from each of the 4 GIS layers were added together to achieve a total score for each pixel that reflected the suitability of that area for black-tailed prairie dogs. The scores were then divided into potential habitat classes based on relative values of total scores (Roy et al. 1995; Sperduto and Congalton 1996). Classes with higher scores received a more favorable suitability rating than classes with lower scores.

The potential habitat layer was then smoothed to remove small islands of pixels with the use of a filter that excluded any clusters of $<50$ contiguous pixels (Breininger et al. 1991; Herr and Queen 1993). This was done prior to integration of the remotely sensed data, and it resulted in a more ecologically sensible and easily interpreted map of potential habitat, with fewer small patches of different classes mixed together (Fig. 3). Habitat classes with the lowest suitability rating were assigned the largest size filter, whereas classes with the highest suitability rating were assigned the smallest filter. Thus, classes representing potential colonies in the classification of the imagery that were found in areas with a low habitat rating needed to be relatively large to be considered a colony. This filtering process was intended to exclude clusters of pixels representing apparent colonies (false positives) located in areas with a low-quality habitat. For example, areas of bare soil were typically classified as colonies, but they had very different soil types resulting in a low potential habitat rating, and were thereby excluded. Conversely, classes representing apparent colonies in the classification that were found in areas with a high habitat rating could be much smaller and still considered a colony. This process created a weighted model to serve as a filter for the remotely sensed data (Sperduto and Congalton 1996).

\section{Aerial Reconnaissance Data Analysis}

These data was delivered as a series of points collected during the reconnaissance flight. The data was input into a GIS, attributed for date of flight, direction of flight, and presence/ absence of colonies. An 800-m buffer zone was created on either side of each flight line. An area was then delineated in the GIS that corresponded to the area that the observer classified as colony or noncolony, on either side of the plane (Fig. 2).

\section{Accuracy Assessment and Kappa Analysis}

A critical part of any remote sensing project is determining the accuracy of the classification (Meyer and Werth 1990; Congalton 1991). The field data points were added to the GIS to conduct the accuracy assessment. The same field points were used in the analyses of all 3 remote sensing methods (raw satellite imagery, enhanced satellite imagery and aerial reconnaissance). The field study identified areas on the ground as active-colony, inactive-colony, or noncolony. However, these were lumped into 2 classes, colony and noncolony, because the

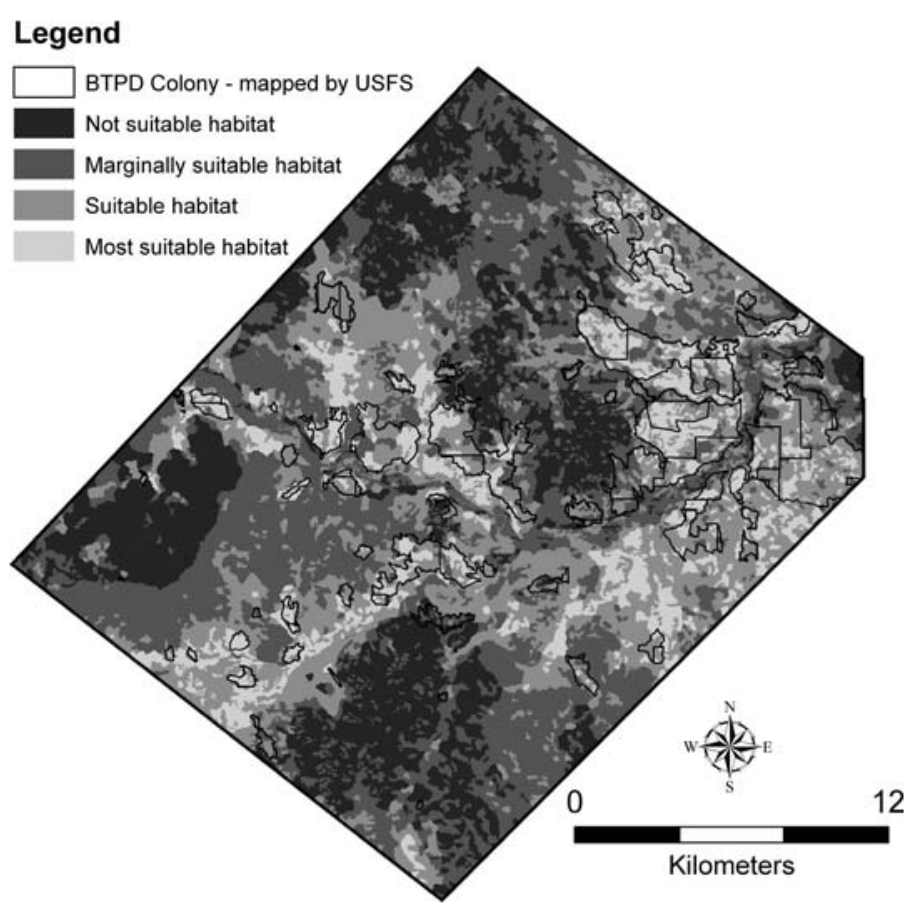

Figure 3. Map of the potential black-tailed prairie dog habitat in eastern Wyoming (summation of the 4 thematic/ecological layers) after smoothing. The colonies from the 1996-97 GIS layer are shown outlined in black for comparison with habitat classes (the colony layer was not used in the analysis). Image processing was conducted with the use of ERDAS IMAGINE 8.4 and ENVI 3.4; map was created with the use of ArcView GIS 9.1 .

aerial reconnaissance data did not differentiate between active and inactive colonies.

An error matrix was constructed for each classification to determine overall, producer's, and user's accuracies (Congalton and Green 1999). The Kappa analysis generated the $K_{\text {HAT }}$ statistic, a measure of accuracy based on the difference between actual and chance agreement in the error matrix (Cohen 1960). Generating the variance of $\mathrm{K}_{\mathrm{HAT}}$ allows for significance to be tested with the use of a $Z$ test (Congalton and Green 1999).

\section{RESULTS}

\section{Satellite Imagery Analysis}

The final, supervised classification resulted in 2 classes: noncolony and colony. The noncolony class was an aggregation of riparian zones, bare soil, grassland (not grazed by prairie dogs), sagebrush, and coniferous woodland. These areas were lumped together after the classification was performed. The colony class, representing active or inactive colonies, occupied approximately $27 \%$ of the inner study area, with the noncolony class occupying the remaining $73 \%$ of the area. The spatial distribution of these classes was as expected, with a characteristic heterogeneity of the colony class within the matrix of the noncolony class (Fig. 4). The $K_{\text {HAT }}$ value was 0.28 and the $Z$ statistic was 4.0184 (Table 1 ). At the $95 \%$ confidence level the critical value for the $Z$ statistic would be 1.96. Therefore this method of 


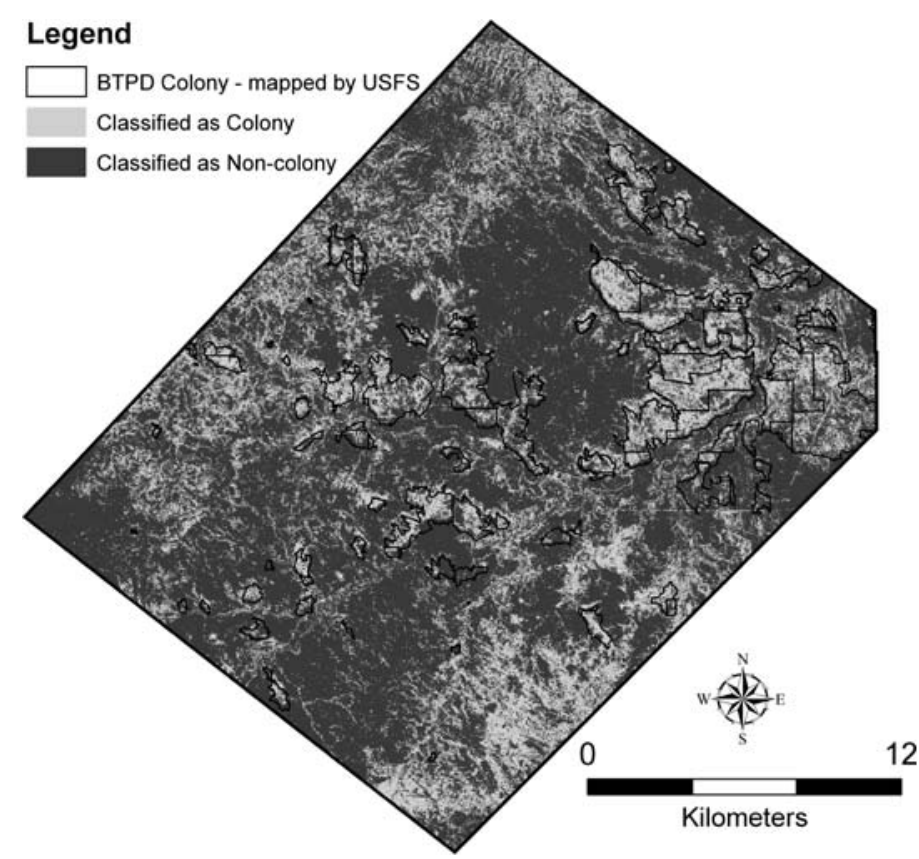

Figure 4. Map of the study area of black-tailed prairie dog habitat in eastern Wyoming using the raw satellite imagery method (from the image classification). Colony outlines shown in black. Image processing was conducting with the use of ERDAS IMAGINE 8.4 and ENVI 3.4; map was created with the use of ArcView GIS 9.1.

remote sensing can detect black-tailed prairie dog colonies at a frequency greater than chance alone.

\section{GIS Data Analysis}

The slope layer was divided into classes of 2-degree increments to simplify the assessment. The analysis $\left(\chi^{2}=23531\right.$, df $=29$, $P<0.001)$ indicated that the frequency of colony and noncolony pixels in slope classes were significantly different than chance. The $\chi^{2}$ value of each individual slope class was then analyzed to determine the contribution of each class to the total $\chi^{2}$ value. Individual $\chi^{2}$ values were considered to be significant if they were $>3.84(\mathrm{df}=1, \alpha=0.05)$. Scores were allocated based on the size of the $\chi^{2}$ value, with negative scores being assigned if the difference between the observed and expected numbers of pixels was $<0$. Approximately half of the slope classes differed significantly from the expected value and were determined to contribute substantially to the overall $\chi^{2}$ value. Only classes $0-2$ and 28-30 received positive scores, with remaining classes generating scores between zero and negative 4 .

The classes used in the land-cover analysis were the same as the primary cover classes used in the Wyoming Gap Analysis (1996) land cover. There were 12 land-cover classes used in the analysis, but just 8 of these were present in the inner study area, so only these scores were transferred into the inner study area. The analysis indicated that the frequency of pixels in the landcover classes were not randomly distributed with respect to colonies $\left(\chi^{2}=37246, \mathrm{df}=11, P<0.001\right)$. The assessment exhibited a strong polarity of results, with virtually all of the classes generating scores of positive 3 or 4 , or negative 3 or 4 .
Table 1. Error matrix for the accuracy assessment of the raw satellite imagery method. The $\mathrm{K}_{\mathrm{HAT}}$ value for this method was 0.28 ; variance $=0.0048 ; Z$ statistic $=4.0184(P<0.05)$.

\begin{tabular}{lccc}
\hline & \multicolumn{2}{c}{ Reference data } & \\
\cline { 2 - 3 } Classified data & Colony & Noncolony & Row total \\
\hline Colony & 48 & 16 & 64 \\
Noncolony & 72 & 111 & 183 \\
Column total & 120 & 127 & 247 \\
\hline
\end{tabular}

The only exception was the desert shrub class, which was found to be insignificant and resulted in a score of zero. The only classes receiving positive scores were dry-land crop $(+4)$ and mixed-grass prairie $(+3)$.

The soil analysis layer was divided into soil map units based on the available soil survey (Reckner 1988; Kee 1990). The analysis strongly suggested that the frequency of pixels in the soil type classes in the study area differed from chance with respect to prairie dog colonies $\left(\chi^{2}=332517\right.$, df $=193$, $P<0.001)$. The $\chi^{2}$ analysis of each individual soil class revealed that all but 5 of the 194 soil map unit classes made significant contributions to the overall $\chi^{2}$ value. This analysis also exhibited a strong polarity of scores with 24 classes in the inner study area receiving the highest or lowest possible score.

The NDVI analysis was consistent with a nonrandom distribution of prairie dog colonies among classes $\left(\chi^{2}=1613\right.$, $\mathrm{df}=9, P<0.001)$. Classes 1,9 , and 10 were inversely associated with prairie dog colonies and received negative scores $(-3$ to -2$)$, whereas class 8 had a score of zero. Classes 2 through 7 were directly associated with prairie dog colonies, generating scores of +2 or +3 .

\section{Enhanced Satellite Imagery Analysis}

The potential habitat data was derived from the GIS analysis and was a summation of the 4 ecological layers. The scores from each of these layers were added together to achieve a total score for each pixel ranging from -15 to +15 . Scores ranging from -15 to -9 were assigned to the not suitable habitat class; scores ranging from -8 to -1 to the marginally suitable class; scores of 0 to +8 to the suitable class; and finally scores ranging from +9 to +15 to the highly suitable habitat class. The marginally suitable habitat class occupied the largest amount of study area (36\%), followed by the suitable class (31\%). The not suitable and most suitable habitat classes occupied $21 \%$ and $11 \%$, respectively.

Once the remote sensing data was integrated with the GIS data the filter was applied to the aggregates of colony pixels within each class. Accordingly, a 100-pixel cluster filter was used for the not suitable class, an 80-pixel filter for the marginally suitable class, a 60-pixel filter for the suitable class, and a 40-pixel filter for the bighly suitable class. This postfiltered classification had a smoothing effect, resulting in a substantially different output image (Fig. 5) compared to the raw satellite image (Fig. 4).

In the postfiltered outcome, the matrix (noncolony class) decreased from 73 to $69 \%$, while the patches (colony class) increased from 27 to $31 \%$. The $\mathrm{K}_{\mathrm{HAT}}$ value of the post-filtered 


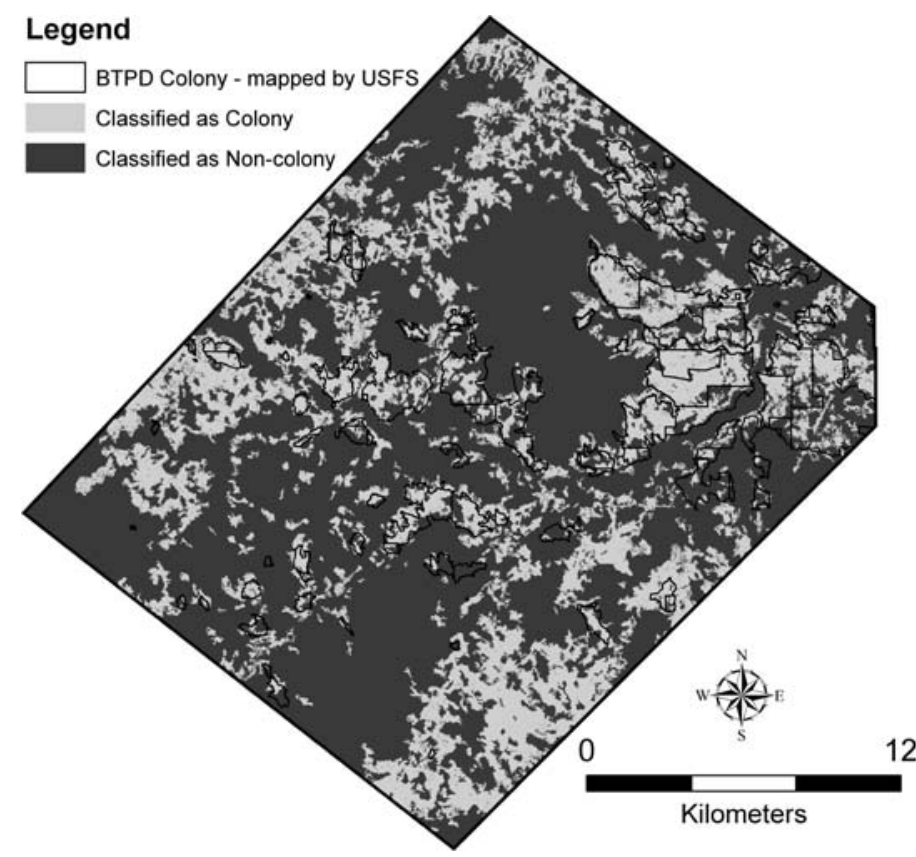

Figure 5. Map of the study area of black-tailed prairie dog habitat in eastern Wyoming with the use of the enhanced satellite imagery method (the image classification coupled with the thematic data). Colony outlines shown in black. Image processing was conducted with the use of ERDAS IMAGINE 8.4 and ENVI 3.4; map was created with the use of ArcView GIS 9.1.

classification was 0.38 and the $Z$ statistic was 6.2294 (Table 2). Therefore, at the $95 \%$ confidence level the enhanced remote sensing can detect black-tailed prairie dog colonies at a rate that is better than chance.

\section{Aerial Reconnaissance Data Analysis}

A map was generated from this data based on the methodology illustrated in Figure 2. The $K_{\mathrm{HAT}}$ value was 0.31 and the $Z$ statistic was 5.0767 (Table 3). Therefore this method also detected black-tailed prairie dog colonies at a rate better than chance, at the $95 \%$ confidence level.

\section{Accuracy Assessment}

The overall, producer's and user's accuracies showed marked differences among the monitoring methods (Table 4). The overall accuracy of the raw satellite imagery method was $64 \%$, and the accuracy increased to $69 \%$ when that method was enhanced with thematic (ecological) data. The aerial reconnaissance method had an overall accuracy of $65 \%$, just

Table 2. Error matrix for the accuracy assessment of the enhanced satellite imagery method (integrated with thematic/ecological data). The $\mathrm{K}_{\text {HAT }}$ value for this method was 0.38 ; variance $=0.0038$; $Z$ statistic $=6.2294(P<0.05)$.

\begin{tabular}{lccc}
\hline & \multicolumn{2}{c}{ Reference data } & \\
\cline { 2 - 3 } Classified data & Colony & Noncolony & Row total \\
\hline Colony & 65 & 21 & 86 \\
Noncolony & 55 & 106 & 161 \\
Column total & 120 & 127 & 247 \\
\hline
\end{tabular}

Table 3. Error matrix for the accuracy assessment of the aerial reconnaissance data. The $\mathrm{K}_{\mathrm{HAT}}$ value for this method was 0.31 ; variance $=0.0038 ; Z$ statistic $=5.0767(P<0.05){ }^{1}$

\begin{tabular}{lccc}
\hline & \multicolumn{2}{c}{ Reference data } & \\
\cline { 2 - 3 } Classified data & Colony & Noncolony & Row total \\
\hline Colony & 98 & 65 & 163 \\
Noncolony & 26 & 72 & 98 \\
Column total & 124 & 137 & 261 \\
\hline
\end{tabular}

${ }^{1}$ The total number of reference points for the aerial reconnaissance method (261) is different than the 2 satellite imagery methods because some of the line transects from this method overlapped each other.

slightly better than the raw satellite imagery method. Overall accuracy is a good general indicator, although other types of accuracies provide more detailed information and reveal the efficacy of methods in terms of management.

The aerial reconnaissance method generated the highest producer's accuracy among the colony classes; $79 \%$ of this class area was correctly identified. The raw satellite imagery method had the lowest producer's accuracy for colonies $(40 \%)$. The raw satellite imagery method had the highest producer's accuracy for the non-colony class $(87 \%)$, whereas the aerial reconnaissance method had the lowest producer's accuracy for that class $(53 \%)$.

The user's accuracy for the colony class was highest with the raw satellite imagery method. That is, $75 \%$ of an area within this map class actually represented that class on the ground. This accuracy was lowest with the aerial reconnaissance method $(60 \%)$. For the noncolony class, the aerial reconnaissance method generated the highest user's accuracy $(74 \%)$, whereas the raw satellite imagery method had the lowest user's accuracy $(61 \%)$.

\section{DISCUSSION}

\section{GIS Data Analysis}

Black-tailed prairie dogs prefer areas with little to no slope, provided there is a minimal flooding hazard (Koford 1958). Several studies conducted in similar habitat have reported that colonies usually occurred on areas with slopes $<9 \%$ (Dalsted

Table 4. Accuracies for the 3 remote sensing methods for black-tailed prairie dog colonies in eastern Wyoming.

\begin{tabular}{lccc}
\hline & $\begin{array}{c}\text { Satellite imagery } \\
\text { method (raw) }\end{array}$ & $\begin{array}{c}\text { Satellite imagery } \\
\text { method (enhanced) }\end{array}$ & $\begin{array}{c}\text { Aerial } \\
\text { reconnaissance } \\
\text { method }\end{array}$ \\
\hline $\begin{array}{l}\text { Overall accuracy } \\
\text { Producer's accuracy }\end{array}$ & $64.4 \%$ & $69.2 \%$ & $65.1 \%$ \\
Colony & $40.0 \%$ & $54.2 \%$ & $79.0 \%$ \\
Noncolony & $87.4 \%$ & $82.8 \%$ & $52.6 \%$ \\
User's accuracy & & & \\
$\quad$ Colony & $75.0 \%$ & $75.5 \%$ & $60.1 \%$ \\
$\quad$ Noncolony & $60.7 \%$ & $66.0 \%$ & $73.5 \%$ \\
\hline${ }^{1}$ The overall accuracy was calculated from the numbers located on the diagonal in Tables 1-3.
\end{tabular}


et al. 1981; Reading and Matchett 1997). The importance of slope appears to be a function of associated ecological factors, such as soil depth and texture (i.e., less slope is associated with more soil), which can influence the composition of vegetation. The present results are generally consistent with these previous findings. In our analysis, areas with no slope, up to approximately $4.5 \%$ slope, received the highest possible score. Our analysis also indicated a negative trend in habitat suitability with increasing slope, as expected from earlier studies (Koford 1958; Dalsted et al. 1981; Reading and Matchett 1997).

The land-cover analysis identified mixed-grass prairie and dry-land crop classes as having positive associations with prairie dog colonies, as expected. The dry-land crop class was limited within the study area and represented remnant areas of dry-land agriculture that persisted after homesteads were abandoned; crops are no longer grown within the study area. However, this is an interesting finding because some of the best lands for agriculture overlap considerably with potential blacktailed prairie dog habitat (Koford 1958). The mixed-grass prairie class occupied the majority of the study area and is the preferred land cover type of black-tailed prairie dogs (Koford 1958; Hoogland 1995).

The 5 remaining classes, which primarily contained woodlands and shrublands, received negative scores. Included in this was a grass-dominated riparian class (confined to the Cheyenne River), which may prohibit colony establishment due to the seasonal flooding of the stream (Assal 2001). The Wyoming big sagebrush class also received a low score. Black-tailed prairie dog colonies do not typically occupy dense shrublands, although it is common for them to be found in areas of less dense shrubs such as sagebrush, which they actively prune and can prevent subsequent encroachment (Osborn 1942; Weltzin et al. 1997).

The sagebrush class illustrates a problem with using this type of coarse data. The land-cover layer that was created by the Gap analysis classified the cover types of areas based on the majority rule (Wyoming Gap Analysis 1996). Therefore, although the area occupied by shrubs was in the majority, the condition and density of shrubs were not taken into account.

Soil classes generating the highest scores contained complexes that were composed of deep, well-drained sandy loams, clay loams, and loams (Reckner 1988; Kee 1990). Essentially, all of the soil types with high association scores were welldrained with moderately deep to deep profiles. Drainage and depth are 2 major factors with regard to soil preferences of black-tailed prairie dogs (Dalsted et al. 1981). Soil classes with the lowest scores had relatively steeper slopes, shallow depths, or flooded conditions associated with them (Reckner 1988; Kee 1990). Soils found on flood plains and low terraces, with shallow profiles and a high probability of flooding; as well as rock outcrops, which are not conducive to prairie dog habitat (Dalsted et al. 1981), were all associated with low scores.

It appears that no previous study has examined the relationship between prairie dog colonies and NDVI. However, we hypothesized that black-tailed prairie dog colonies would have lower NDVI values than adjacent grassland because there would be less green biomass present on colonies (Tucker et al. 1985). Although this trend was readily apparent, the classes with lower NDVI values were not invariably associated with prairie dog colonies. Class 1 (bare soil and rock) had a low association score and corresponded with the lowest NDVI values. This is consistent with field observations because colonies were partially vegetated, indicating a higher NDVI than an area completely lacking vegetation.

Using satellite imagery to garner information about vegetation can be difficult when vegetative cover is $<30 \%$ (Campbell 1996), a common condition throughout the study area. However, NDVI often is useful in determining relative amounts of biomass over large tracts of land such as in this study. Moreover, the aforementioned relationship (bare soil versus heavily grazed colonies) suggests that this index was sensitive to very slight differences in vegetation.

Livestock grazing must be considered in interpreting NDVI. Over 45000 sheep and cattle graze on the combined ownership areas within Thunder Basin National Grassland. Livestock reduce vegetative cover and expose soil, especially in areas that are in close proximity to water sources. They do not graze in the same patterns as prairie dogs and are bounded by fewer physiographic obstacles but may be constrained by anthropogenic features. Fence lines were apparent in portions of the image that revealed long, straight edges of heavy grazing. Nonetheless, potential prairie dog habitat overlaps considerably with areas used by livestock grazing, and the effects of sheep and cattle undoubtedly created a source of error within the analyses.

The enhanced satellite imagery (Fig. 5) contains sizable areas in the northern, western, and southern portions of the study area that were identified as colonies, but were not actual colonies (false positives). This appears to be a function of the filtering process. In the raw satellite imagery (Fig. 4), these same areas produce a mixed pattern between the 2 classes. The habitat suitability analysis (Fig. 3) largely identifies these areas as not suitable and marginally suitable. It was apparent that there were areas in the image where many of the pixel clusters in the colony class were connected (Fig. 4). The filter failed to exclude these connected clusters of pixels in many of these areas. In turn, the noncolony class pixels were removed from within these areas, thus reducing the total area occupied by the noncolony class and increasing the total area covered by the colony class. Essentially, one of the shortcomings of the habitat filter is the apparent creation of colonies from noisy areas of the image classification (compare Figs. 4 and 5).

\section{Accuracy Assessment}

The postfiltered, supervised classification generated a 5\% increase in overall accuracy compared to the prefiltered classification. This $69 \%$ accuracy might not be adequate for management consideration; however, this technique provides a solid method for identifying potential black-tailed prairie dog habitat (Fig. 3). Moreover, these findings suggest that the integrated model approach is an effective means of increasing the accuracy of remotely sensed data. With GIS enhancement, the producer's accuracy of the colony class increased $14 \%$; however, the accuracy for the noncolony class decreased $4 \%$. The user's accuracy of the colony class improved slightly $(76 \%)$, whereas the noncolony class had a $6 \%$ increase.

The user's accuracy is typically a much more important measure for land and wildlife managers because of its use in quantifying and displaying the classes of interest (e.g., maps for ground-based surveying of prairie dog colonies and population estimations). This accuracy reflects the percentage of areas 
within a map class that actually represents that class on the ground. The aerial reconnaissance method had the highest user's accuracy for the noncolony class $(74 \%)$, but the lowest $(60 \%)$ for the more important, colony class. The raw satellite imagery produced very similar results. The enhanced satellite imagery method yielded median scores for both classes; $76 \%$ for the colony class and $66 \%$ for the noncolony class. These results suggest the latter method is superior when the accuracy of both classes is important to land managers.

\section{Sources of Error}

One of the major difficulties encountered when using remotely sensed data is the problem of spectral mixing. The problem can occur if a single pixel contains 2 different land-cover types, such as dense vegetation and bare soil. This problem is most troublesome with spectral data collected over somewhat sparsely vegetated targets that exhibit a mixture of plant and soil backgrounds (Elvidge and Lyon 1985; Huete et al. 1985), commonly found on the landscape of the study area. Blacktailed prairie dog activities change the microlandscape of their colonies by clipping vegetation, but these changes are not consistent throughout a colony. Often, small ribbons of vegetation, such as shrubs and taller herbaceous plants, remain within the boundaries of a colony. Thus, spectral mixing is a problem for satellite imagery of rangeland and is further complicated by the activities of black-tailed prairie dogs. The aerial reconnaissance method did not have the problem of spectral mixing.

Perhaps the greatest error was a consequence of the changes caused by the sylvatic plague, a devastating disease to prairie dogs that can quickly wipe out entire colonies (Armitage 1981; Barnes 1993). The most recent outbreak of plague was reported in the study area in the spring of 2001, although it could have been present as early as the fall of 2000 (T. Byer, USFS, personal communication, June 2001). It spread throughout the study area during the spring and summer of 2001. This presented a problem because the satellite image was acquired on 19 July 2000, and ground truthing was conducted during the summers of 2000 and 2001. This time lag, during which disease decimated some colonies, adversely affected the supervised classification. Following the demise of a colony, the vegetation typically takes 3-5 years to recover. Drought may extend this recovery period, and the study area has received below-average rainfall the last 3-4 years (Assal 2001). This condition allows different aged inactive colonies to maintain similar spectral signatures, making it difficult to distinguish active colonies from inactive colonies. This source of error similarly afflicted both the remote sensing and the aerial reconnaissance methods. The 2 satellite imagery methods have an advantage over the aerial reconnaissance method in that there was no observer error or bias. The observer might not have been consistent during observation, given factors such as lighting (i.e., morning or afternoon versus midday) and fatigue. Finally, even a small delay in marking a GPS point at an altitude of $152 \mathrm{~m}$ while traveling $160 \mathrm{~km} /$ hour could lead to a substantial error in the location of a colony boundary.

\section{Economics and Logistics}

Comparison of the 3 methodologies would not be complete without considering cost. Including both the cost of data acqui- sition and technical analysis, the aerial reconnaissance method had a higher cost ( $\$ 3$ 800) than both satellite imagery methods. The raw satellite imagery method was cheaper (\$1 605) than the enhanced satellite imagery method (\$3 605). It is important to note that the thematic data used in this project was secured at no cost (Assal 2001). The only additional cost to the enhanced method was technical analysis; although it produced a substantially higher level of accuracy.

The lower cost of the satellite imagery methods would become even more advantageous if the area of interest was expanded. Satellite imagery provides a much larger coverage area than the aerial reconnaissance method. Landsat ETM+ provides scenes that are $185 \mathrm{~km}$ wide by $170 \mathrm{~km}$ long; recorded 22 times each year. To aerially survey such an area would require $>100$ hours of flight, along with the attendant risks of low-altitude reconnaissance. Unfortunately, since this research was conducted, the scan line corrector (SLC) on Landsat ETM + malfunctioned, resulting in a $22 \%$ loss of each scene. However, the USGS/NASA Landsat team is developing means to compensate for the SLC malfunction, such as using multiple images to fill data gaps. These methods should provide sufficient spatial and temporal coverage to still benefit research of this nature.

\section{MANAGEMENT IMPLICATIONS}

In summary, given considerations of accuracy, logistics, and cost, satellite-imagery methods appear to be a better choice for mapping black-tailed prairie dog colonies at the landscape scale. Depending on funding and the availability of data, the enhanced satellite imagery method provides better accuracy than the raw satellite imagery method. In some cases nearly a $70 \%$ overall accuracy might not be adequate for management considerations. However, this technique does provide a reliable method for identifying potential black-tailed prairie dog habitat (Fig. 3). These data can serve the land manager in the form of a coarse filter to identify large areas of contiguous habitat as well as habitat for other species. These areas can then be efficiently targeted for more expensive and laborious groundbased surveys or higher resolution imagery (e.g., Ikonos, with 1-m panchromatic resolution) can be obtained for analysis. Both of these more fine-scaled methods are too costly for assessing very large areas, but a 2-tiered approach-with an inexpensive coarse-filter approach followed by one of the more detailed analyses-could be economically practical.

In the authors' opinion, the enhanced imagery technique could be applicable to similar ecosystems throughout the western United States, particularly areas intersected with varying slope types. The size of the area of interest will limit chances for ground surveys, but the 2-tiered approach may prove tenable. The best time of year to secure imagery will vary depending on local precipitation patterns, but late spring/early summer was found to produce the greatest contrast between colonies and adjacent grassland.

\section{ACKNOWLEDGMENTS}

The authors would like to thank the funding agencies and those who provided reviews of this manuscript. 


\section{LITERATURE CITED}

Armitage, K. B. 1981. Sociality as a life-history tactic of ground squirrels. Oecologia 48:36-49.

AssaL, T. J. 2001. Detection of black-tailed prairie dog colonies on Wyoming mixed-grass prairie integrating remote sensing and GIS [thesis]. Laramie, WY: University of Wyoming. $123 p$.

BARnES, A. M. 1993. A review of plague and its relevance to prairie dog populations and the black-footed ferret. In: J. L. Oldemeyer, D. E. Biggins, B. J. Miller and $R$. Crete (EDS.). Proceedings of the symposium on the management of prairie dog complexes for the reintroduction of black-footed ferrets. Washington, DC: United States Fish and Wildlife Services, Biological Report No. 93. p 28-37.

Breininger, D. R., M. J. Provancha, And R. B. Smith. 1991. Mapping Florida scrub jay habitat for purposes of land-use management. Photogrammetric Engineering and Remote Sensing 57:1467-1474.

Campbell, J. B. 1996. Introduction to remote sensing. 2nd ed. New York, NY: Guilford Press. 622 p.

COHEN, J. 1960. A coefficient of agreement for nominal scales. Educational and Psychological Measurement 20:37-40.

Congalton, R. G. 1991. A review of assessing the accuracy of classifications of remotely sensed data. Remote Sensing of Environment 37:35-46.

Congalton, R. G., and K. G. Green. 1999. Assessing the accuracy of remotely sensed data: Principles and practices. Boca Raton, FL: Lewis Publishers. $160 \mathrm{p}$.

Dalsted, K. J., S. Sather-Blair, B. K. Worcester, and R. Klukas. 1981. Application of remote sensing to prairie dog management. Journal of Range Management 34:218-223

ELVIDGE, C. D., AND R. J. P. LYON. 1985. Influence of rock-soil spectral variation on the assessment of green biomass. Remote Sensing of Environment 17:265279.

HerR, A. M., And L. P. Queen. 1993. Crane habitat evaluation using GIS and remote sensing. Photogrammetric Engineering and Remote Sensing 59:1531-1538.

Hoogland, J. L. 1995. The black-tailed prairie dog: Social life of a burrowing mammal. Chicago, IL: The University of Chicago Press. 557 p.

Huete, A. R., R. D. Jackson, and D. F. Post. 1985. Spectral response of a plant canopy with different soil backgrounds. Remote Sensing of Environment 17:37-53.

Jorge, L. A. B., AND G. J. Garcia. 1997. A study of habitat fragmentation in southeastern Brazil using remote sensing and geographic information systems (GIS). Forest Ecology and Management 98:35-47.

KeE, G. F. 1990. Soil survey of Weston County, Wyoming. Laramie, WY: Soil Conservation Service, Wyoming Agricultural Experiment Station. 291 p.

KofoRd, C. B. 1958. Prairie dogs, whitefaces, and blue grama. Wildlife Monographs 3:1-78.

LATCHININSKY, A. V. 2001. Environmental factors governing population dynamics of rangeland grasshoppers: The first application of GIS and remote sensing to acridology in Russia [dissertation]. Laramie, WY: University of Wyoming. $270 \mathrm{p}$.

LLoYD, C. J. 1999. Statistical analysis of categorical data. New York, NY: John Wiley \& Sons, Inc. 468 p.

McGREGOR, S. J. 1998. An integrated geographic information system approach for modeling the suitability of conifer habitat in an alpine environment. Geomorphology 21:265-280.

MeYer, M., and L. Werth. 1990. Satellite data: Management panacea of potential problem? Journal of Forestry 88:10-13.
Osborn, B. 1942. Prairie dogs in shinnery (oak scrub) savannah. Ecology 23 $110-115$

Porwal, M. C., P. S. Roy, and V. Chellamuthu. 1996. Wildlife habitat analysis for 'sambar' (Cervus unicolor) in Kanha National Park using remote sensing. International Journal of Remote Sensing 17:2683-2697.

Prasad, S. N., S. P. Goyal, P. S. Roy, and S. Singh. 1994. Changes in wild ass (Equus emionus khur) habitat conditions in Little Rann of Kutch, Gujarat from a remote sensing perspective. International Journal of Remote Sensing 15:3155-3164.

Reading, R. P., and R. Matchett. 1997. Attributes of black-tailed prairie dog colonies in northcentral Montana. Journal of Wildlife Management 61:664673.

ReCKNeR, R. L. 1988. Soil survey of Converse County, Wyoming (northern part). Laramie, WY: Soil Conservation Service, Wyoming Agricultural Experiment Station, $184 \mathrm{p}$.

Rouse, J. W., R. H. Haas, J. A. Schell, and D. W. Deering. 1974. Monitoring vegetation systems in the Great Plains with ERTS. In: Proceedings, Third Earth Resources Technology Satellite-1 Symposium. Greenbelt, MD: NASA SP-351. p 3010-3017.

Roy, P. S., S. A. Ravan, N. Rajadnya, K. K. Das, A. Jain, and S. Singh. 1995. Habitat suitability analysis of Nemorhaedus gora/ A remote sensing and geographic information system approach. Current Science 69:685-691.

SidLE, J. G., D. H. Johnson, AND B. R. EuLiss. 2001. Estimated areal extent of blacktailed prairie dog colonies in the northern Great Plains. Journal of Mammology 82:928-936.

Sperduto, M. B., and R. G. Congalton. 1996. Predicting rare orchid (small whorled pogonia) habitat using GIS. Photogrammetric Engineering \& Remote Sensing 62:1269-1279.

Stehman, S.V., and R. L. Czaplewski. 1998. Design and analysis for thematic map accuracy assessment: Fundamental principles. Remote Sensing of Environment 64:331-344.

Tou, J. T., and R. C. Gonzalez. 1974. Pattern recognition principles. Reading, MA: Addison-Wesley. $377 \mathrm{p}$.

Tucker, C. J., C. L. Vanpraet, M. J. Sharman, and G. Van Ittersum. 1985. Satellite remote sensing of total herbaceous biomass production in the Senegalese Sahel, 1980-1984. Remote Sensing of Environment 17:233-249.

U.S. Geological Survey. 1999. 30 meter National Elevation Dataset (tiled for Wyoming). Sioux Falls, SD: EROS Data Center.

Verlinden, A., AND R. MAsogo. 1997. Satellite remote sensing of habitat suitability for ungulates and ostrich in the Kalahari of Botswana. Journal of Arid Environments 35:563-574.

Wallin, D. O., C. C. H. Elliott, H. H. Shugart, C. J. Tucker, and F. Wilhelmi. 1992. Satellite remote sensing of breeding habitat for an African weaver-bird. Landscape Ecology 7:87-92

Weltzin, J. F., S. Archer, and R. K. Heitschmidt. 1997. Small-mammal regulation of vegetation structure in a temperate savanna. Ecology 78:751-763.

Wheater, C. P., and P. A. Cook. 2000. Using statistics to understand the environment. New York, NY: Routledge. $245 \mathrm{p}$.

WILKIE, D. S., AND J. T. FINN. 1996. Remote sensing imagery for natural resource monitoring. New York, NY: Columbia University Press. 295 p.

Wu, X. B., and F. E. Smeins. 2000. Multiple-scale habitat modeling approach for rare plant conservation. Landscape and Urban Planning 51:11-28.

Wyoming Gap Analysis. 1996. Land cover for Wyoming. Laramie, WY: University of Wyoming, Spatial Data and Visualization Center. 